\title{
The Ceramics from a Late Caddo Site on Mud Creek in Cherokee County, Texas
}

Timothy K. Perttula

Heritage Research Center, Stephen F. Austin State University

Follow this and additional works at: https://scholarworks.sfasu.edu/ita

Part of the American Material Culture Commons, Archaeological Anthropology Commons, Environmental Studies Commons, Other American Studies Commons, Other Arts and Humanities Commons, Other History of Art, Architecture, and Archaeology Commons, and the United States History Commons

Tell us how this article helped you.

This Article is brought to you for free and open access by the Center for Regional Heritage Research at SFA ScholarWorks. It has been accepted for inclusion in Index of Texas Archaeology: Open Access Gray Literature from the Lone Star State by an authorized editor of SFA ScholarWorks. For more information, please contact cdsscholarworks@sfasu.edu. 


\section{The Ceramics from a Late Caddo Site on Mud Creek in Cherokee County, Texas \\ Creative Commons License \\ (c) (1) \& 8}

This work is licensed under a Creative Commons Attribution-NonCommercial 4.0 International License 


\title{
The Ceramics from a Late Caddo Site on Mud Creek in Cherokee County, Texas
}

\author{
Timothy K. Perttula
}

\section{INTRODUCTION}

This article discusses the character of a large assemblage of prehistoric Caddo vessel sherds from a Late Caddo site (41CE309) on Mud Creek in Cherokee County, Texas, not far from the creek's confluence with the Angelina River. The site was discovered by Bill Young, an avocational archaeologist and Texas Archeological Steward, on a terrace of Mud Creek, just west of the city of Reklaw, Texas.

During the course of a number of visits to the site in the 1980 s, more than 2300 ceramic sherds were collected by Young, most of the sherds being found in the central part of the terrace landform; in this same area, three or more Caddo burials had been previously looted by collectors. A few sherds and Friley points were noted at the southern part of the terrace, suggesting that archaeological materials from a pre-A.D. 900 Woodland period occupation may be present there as well as a more substantial Late Caddo occupation across the remainder of 41 CE309.

\section{ASSEMBLAGE}

The ceramic vessel sherd assemblage from 41 CE309 includes 2380 sherds. About $2.4 \%$ of the sherds are from Woodland period sandy paste Goose Creek Plain, var. unspecified vessels (including one sandy paste sherd with a row of small circular punctates), while the remainder of the sherds $(n=2323)$ are from tempered Caddo vessels of several different wares. Almost $60 \%$ of these tempered Caddo sherds are from the decorated portions of utility ware and fine ware vessels.

\section{Plain Wares}

The tempered plain wares $(n=954)$ from $41 \mathrm{CE} 309$ includes 41 rims, 852 body sherds, and 61 base sherds. There is a substantial plain ware assemblage of primarily simple bowls, jars, and bottles at the site, as demonstrated by the fact that almost $33 \%$ of the rims from the Caddo ceramic assemblage $(n=125)$ are from plain wares. Nevertheless, the plain to decorated sherd ratio of 0.70 from the site, as well as the preponderance of decorated rims $(67 \%)$, suggests that the majority of the vessels have decoration on either the exterior surface of the rim and/or the body.

\section{Utility Wares}

The utility wares from 41CE309 include 73 rims and 1183 body sherds (Table 1). Utility wares are predominantly from jars used for cooking and food storage, and this ware is certainly the most common kind of pottery vessel made and used at the site by the Caddo people. Approximately $58 \%$ of all the rims from 41 CE309 are from utility wares.

Among the utility wares, the principal decorative methods present at 41 CE309 include incised $(32.9 \%$ of the rims), punctated (23.3\%), and brushed (23.3\%). Including both rim and body sherds, more than $72 \%$ of the 41 CE 309 utility ware sherds have brushing marks on either the rim and/or the body of jars; another $3.8 \%$ have brushed decorations in combination with another decorative method (i.e., incised, punctated, appliqued, and incised-appliqued). Incised jars comprise $13.2 \%$ of the utility wares and jars with punctated decorations another $8 \%$ (see Table 1).

The brushed rims have horizontal brushing marks on them. Most of the remainder of the brushed vessels (and vessels with brushed bodies and non-brushed decorations on the rim) have vertical brushing on vessel bodies $(n=n=833)$. About $6 \%(n=54)$ have overlapping brushed marks on the vessel body, as well as opposed brushing $(n=7$, $0.8 \%)$ and diagonal brushing $(n=1)$ marks. These brushed vessels are likely primarily from Bullard Brushed jars, or types such as Maydelle Incised or Pease Brushed-Incised (see Suhm and Jelks 1962) that have brushed bodies. 
Table 1. Decorated utility wares and fine ware sherds from 41CE309.

\begin{tabular}{lccc}
\hline Ware & Rim & Body & N \\
\hline Utility Ware & 17 & 896 & \\
Brushed & $24^{*}$ & 142 & 166 \\
Incised & 17 & 83 & 100 \\
Punctated & 7 & 17 & 24 \\
Incised-punctated & - & 22 & 22 \\
Brushed-incised & 5 & 11 & 16 \\
Brushed-punctated & - & 7 & 7 \\
Brushed-appliqued & 1 & 2 & 3 \\
Brushed-incised-punctated & 1 & 1 & 2 \\
Appliqued & 1 & 1 & 2 \\
Fingernail-impressed** & - & 1 & 1 \\
Pinched & 73 & 1183 & 1256 \\
Subtotal & & & \\
& & & 111 \\
Fine Ware & 12 & 99 & 2 \\
Engraved & - & 2 & 113 \\
Red-slipped & 12 & 102 & 1369 \\
Subtotal & 85 & 1284 & \\
\hline Totals & & & \\
\hline
\end{tabular}

*two incised rims have Poynor Engraved-style decorative elements, except that they are executed with incised lines.

**Weches Fingernail Impressed, var. Weches (see Stokes and Woodring 1981)

These same sorts of vessels were sometimes decorated on the body with parallel or vertical brushing and sets of vertical incised lines; these brushedincised sherds represent $1.8 \%$ of the utility wares. One of these sherds has parallel brushing marks with incised lines that overlie the brushing. Three sherds from 41 CE309 have brushed-incised-punctated decorative elements (see Table 1). One rim has horizontal brushing marks below a row of tool punctates at the lip, and at least one diagonal incised line drawn through the brushing (Figure 1a). The other two are body sherds with parallel brushing marks alongside a single straight incised line; a row of tool punctates has been pushed through the brushing.

Brushed-punctated decorations on utility wares at 41 CE309 include five rim sherds $(6.8 \%$ of the utility ware rims) and 11 body sherds (1\% of the utility ware body sherds) (see Table 1). All five rims have horizontal brushing marks, three with tool punctations at the lip and two others with a single row of tool punctations underneath an everted rim. The body sherds have parallel brushing marks as well as either rows of tool punctates pushed through the brushing $(n=10)$ or a single row of tool punctates adjacent to an area of brushing; in the latter case, the punctates likely ran vertically on the vessel body.

Seven other body sherds have straight appliqued fillets amidst areas of parallel brushing marks. These appliqued fillets likely served to divide the body of Pease Brushed-Incised jars into panels filled with vertical brushing marks. Two sherds have appliqued decorative elements: a rim with a large appliqued node, and a body sherd with a straight appliqued fillet.

Among the rim sherds with incised decorative elements, five $(22.7 \%)$ have sets of vertical incised lines, eight rims have either horizontal $(18.2 \%)$ or diagonal $(18.2 \%)$ incised lines, and six rims have cross-hatched (13.6\%) or opposed (13.6\%, see Figure 1d) incised lines; the latter rims and the diagonal 


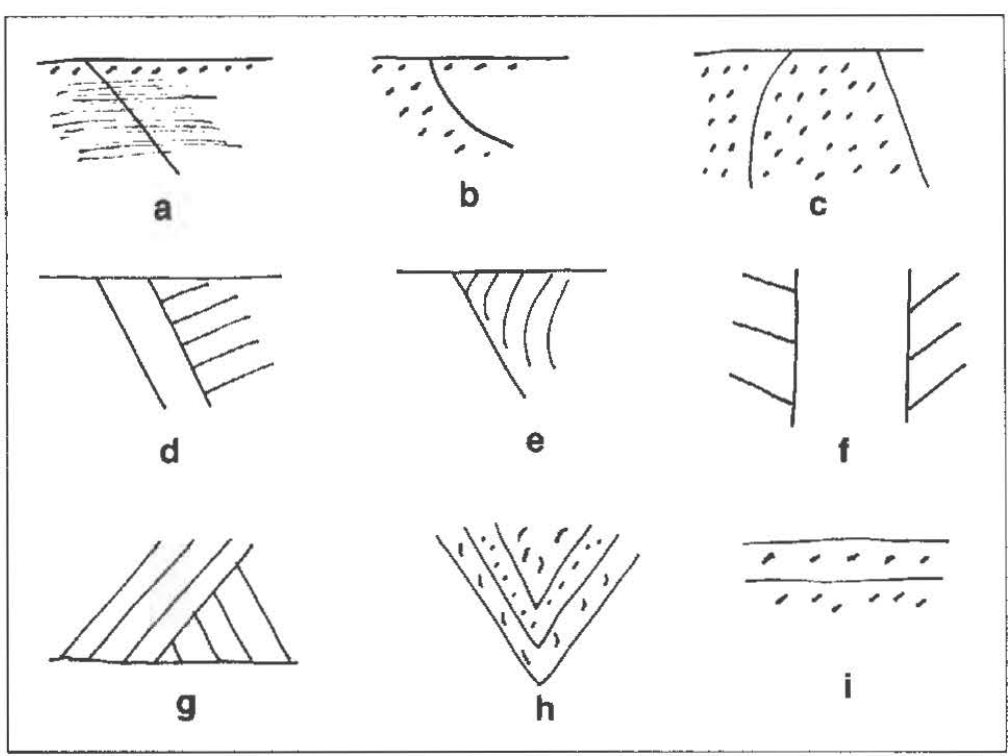

Figure 1. Selected decorative elements in the 41CE309 utility wares: a, brushed-incised-punctated rim sherd; b-c, i, incised-punctated rim sherds; $\mathrm{d}$, incised rim sherd; e, Poynor Incised rim sherd; f-g, incised body sherds; $h$, incised-punctated body sberd.

incised lines are likely from Maydelle Incised jars. Three other incised rims have vertical and diagonal lines $(n=1)$, vertical and diagonal opposed lines $(n=1)$, or curvilinear incised lines $(n=1)$. Most of the incised body sherds have simple straight or geometric decorative elements, the most common being sets of parallel lines $(n=61)$ with different spacing between lines (the majority having closely-spaced lines), single straight lines $(n=36)$, and opposed incised lines $(n=32$, see Figure Ig). Anotber body sherd has incised panels (see Figure 1f), and two body sherds have a single curvilinear incised line.

Three of the incised sherds from 41CE309 are from carinated bowls that have decorative elements otherwise found only on Poynor Engraved vessels; in these cases, the decorative motif was executed before the vessel was fired, rather than after firing. These Poynor Incised vessels include one rim with hatched triangles (see Figure 1e), another rim with an incised circle, scroll, and hatched triangles (Figure 2g), and a body sherd with hatched triangles and diagonal incised lines (also likely part of a scroll element).

The incised-punctated vessel sherds are diverse, even though they only comprise $1.9 \%$ of the utility ware sherds and $9.6 \%$ of the utility ware rims (see Table 1). Two of the rims have horizontal incised lines above tool punctate-filled zones, while two others have a row of tool punctates at the lip and either diagonal or horizontal incised lines on the rim.
Another horizontal incised rim has a row of tool punclates underneath the lip and above the incised lines. Two other incised-punctated rim sherds have curvilinear incised motifs, one with a zone of tool punctates defined by a single curvilinear incised line as well as a single row of tool punctates below the vessel lip (see Figure 1b) and the other with tool-punctated zones on the rim defined by both curvilinear and diagonal incised lines (see Figure Ic).

The majority of the incisedpunctated body sherds have a single straight incised line framing a zone of tool punctates $(n=9)$. Two other body sherds, from Maydelle Incised jars, have incised triangles filled with tool punctates. Other examples include a carinated bowl sherd with horizontal incised lines above the carination and a row of tool punctates below the carination; a body sberd with diagonal opposed incised lines with different kinds of fingernail and tool punctations between the incised lines (see Figure $1 \mathrm{~h}$ ); another body sherd with tool punctated rows between incised lines (see Figure 1i); a body sherd with horizontal lines above a tool punctated row; and a body sherd with opposed incised lines above a zone of fingernail punctates. The one remaining incised-punctated body sherd has a single curvilinear incised line framing a zone of tool punctates.

The punctated utility ware sherds primarily have tool punctations ( $n=72$, including 16 rims) rather than fingernail punctations $(n=28$, but only one rim sherd). The punctations occur in rows on the rim and/or body of utility ware vessels. Ten of the tool punctated rims bave a single row of punctates under the lip of everted rim jars.

Only a single Killough Pinched body sherd is in the collection from 4ICE309. Apparently the Caddo manufacture and use of this distinctive utility ware was most prevalent in the upper part of the Neches River valley (Perttula 2008a).

Two of the utility ware sherds from the site are from pre-A.D. 1300 Weches Fingernail Impressed, var. Weches vessels (see Table 1). These two sherds are the only ceramic material culture evidence of an early Caddo use of 41CE309. 


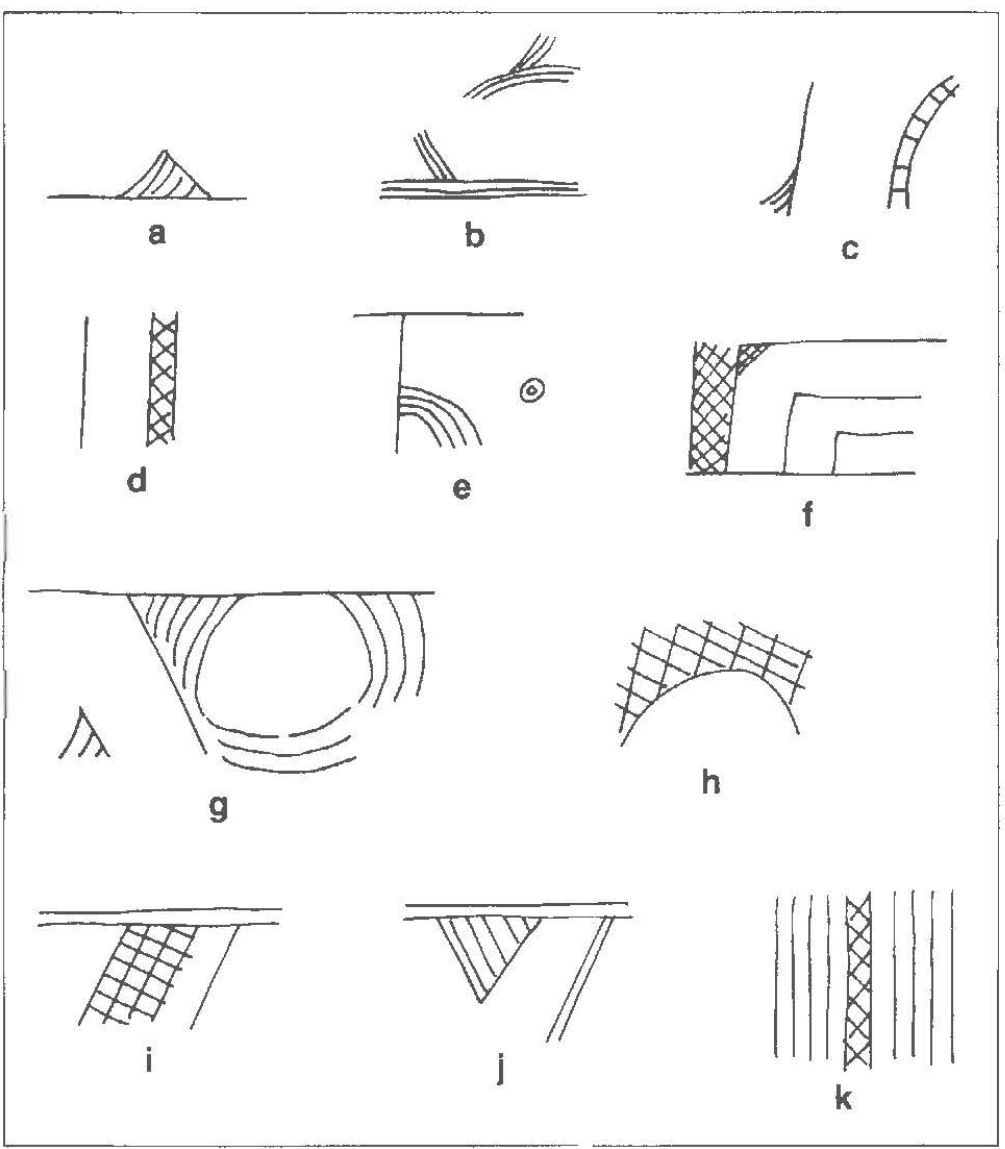

Figure 2. Selected decorative elements in the 4 1CE309 fine wares: and, $f_{2}$ $h$, k, engraved body sherds; e, i-j, engraved rim sherds; $g$, Poynor Incised rim sherd.

\section{Fine Wares}

The engraved and red-slipped fine wares include 12 rims and 101 body sherds (see Table 1). The engraved rims, all from carinated bowls, comprise only $8.8 \%$ of the rims in the Caddo ceramic assemblage as a whole, indicating that fine wares were only relatively rarely made and used during the Late Caddo occupation at 41CE309. The engraved sherds are divided into carinated bowls $(n=100)$ and bottles $(n=11)$.

The diversity in decorative elements among the $41 C E 309$ carinated bowl fine wares is considerable (Table 2). In addition to a number of sherds $(61 \%)$ with relatively simple straight and geometric elements-including horizontal lines $(n=5)$, horizontal and vertical lines $(n=2)$, opposed lines $(n=7)$, cross-hatching $(n=2)$, diagonal lines $(n=3)$, vertical lines $(n=2)$, parallel lines $(n=18)$, and single straight lines $(n=22)$ - there are a few fine ware sherds at 41 CE309 that have semi-circle $(n=4$, see Figure 2e) or curvilinear $(n=3)$ elements $(7 \%)$, but these are in the decided minority. Other simple elements include elongated excised triangles (probably pendant from a larger but unknown rim motif).

The more complex engraved decorative elements primarily include those from Poynor Engraved vessels that feature: (a) hatched triangles in combination with horizontal and/or diagonal engraved lines ( $n=12$, see Figure $2 a . j$ ); (b) hatched panels and narrow zones $(\mathrm{n}=4$, see Figure $2 \mathrm{c})$; (c) cross-hatched zones and panels $(n=13$, see Figure 2d, h-i, k); and (d) scroll elements ( $\mathrm{n}=2$, sec Figure 2f). Two sherds can be identified as Var. B (see Figure 2f) and Var. S (see Figure 2e) versions of Poynor Engraved as defined from a large sample of whole vessels in the upper Neches River basin (Perttula 2008a:Table 6-37). These particular varieties apparently were made and used in that area in the early part of the Late Caddo Frankston phase, dating from ca. A.D. 1400 1480.

Cross-hatched engraved panels are common features of Poynor Engraved, var: Hond, the principal variety of Poynor Engraved in the upper Neches, as well as four other yet unnamed varieties (Var. D, F, G, and M) of Poynor Engraved (Perttula 2008a). Where the temporal context of these varieties is known, they apparently are common elements in stylistic motifs seen on vessels from mortuary contexts that date from ca. A.D. 1400-1560.

Bottle sherds are not common at 41CE309, accounting for less than $10 \%$ of the fine wares. Most of the bottle sherds have widely-spaced curvilinear engraved lines $(n=6)$ or curvilinear and opposed engraved lines ( $n=3$, see Figure $2 b$ ). Onc Poynor Engraved bottle sherd has hatched triangles and engraved scroll elements. The last bottle sherd has a set of opposed engraved lines on the body of the bottle.

Two of the fine ware sherds are red-slipped (see Table 1). One is from a carinated bowl that is redslipped on both interior and exterior vessel surfaces: the other sherd (from a vessel of unknown form) has a red slip only on the exterior vessel surface. 
Table 2. Engraved decorative elements in the 41 CE309 fine ware sherds.

\begin{tabular}{|c|c|c|c|}
\hline Decorative element & $\operatorname{Rim}$ & Body & $\mathrm{N}$ \\
\hline hatched triangle & - & 8 & 8 \\
\hline hatched triangle and narrow hatched zone & - & 1 & 1 \\
\hline horizontal and diagonal lines and hatched triangle & 1 & - & 1 \\
\hline horizontal lines and hatched triangle & 1 & 1 & 2 \\
\hline curvilinear hatched zone & - & 1 & 1 \\
\hline horizontal line and oval outlined by narrow hatched zone & - & 1 & 1 \\
\hline hatched panel & - & 2 & 2 \\
\hline excised triangle & - & 2 & 2 \\
\hline cross-hatched panels and zones & - & 5 & 5 \\
\hline parallel and narrow cross-hatched zone & - & 1 & 1 \\
\hline diagonal cross-hatched zones & 1 & - & 1 \\
\hline curvilinear cross-hatched zones & - & 3 & 4 \\
\hline $\begin{array}{l}\text { horizontal and vertical lines and triangular } \\
\text { cross-hatched zone }\end{array}$ & 1 & - & 1 \\
\hline straight line and narrow cross-hatched zone & - & 1 & 1 \\
\hline horizontal lines, widely-spaced & - & 5 & 5 \\
\hline horizontal and vertical lines & 2 & - & 2 \\
\hline horizontal lines and scroll element & - & 1 & 1 \\
\hline $\begin{array}{l}\text { horizontal interlocking scroll and vertical cross- } \\
\text { hatched panel }\end{array}$ & - & 1 & 1 \\
\hline diagonal and concentric semi-circles & 1 & - & 1 \\
\hline vertical and concentric semi-circles and small circle & 1 & - & 1 \\
\hline opposed lines & - & 7 & 7 \\
\hline cross-hatched lines & - & 2 & 2 \\
\hline diagonal lines & 2 & 1 & 3 \\
\hline vertical lines & 2 & - & 2 \\
\hline parallel lines, widely-spaced & - & 7 & 7 \\
\hline parallel lines, closely-spaced & - & 9 & 9 \\
\hline parallel lines & - & 2 & 2 \\
\hline hatched semi-circle & - & 1 & 1 \\
\hline hatched circle & - & 1 & 1 \\
\hline single straight line & - & 22 & 22 \\
\hline single curvilinear line & - & 3 & 3 \\
\hline Totals & 12 & 88 & 100 \\
\hline
\end{tabular}




\section{Elbow pipe}

There is a single plain elbow pipe sherd in the collection from 41CE309. Such forms of clay pipes began to manufactured after ca. A.D. 1350 in the upper Neches River basin in East Texas (Perttula 2008a).

\section{Sandy-paste Woodland period pottery}

A total of 57 Woodland period sandy paste sherds are in the Bill Young collection from 41CE309. This includes 51 plain body sherds, two plain rims, two base sherds, a body sherd with a drilled suspension hole, and a body sherd with rows of very small circular punctations. Similar decorated sherds have been found in pre-A.D. 800 Woodland period contexts at relatively well-dated and extensive Woodland period components at Lake Naconiche in the Attoyac Bayou drainage in Nacogdoches County, Texas (see Perttula 2008b).

Sandy paste Goose Creek Plain pottery is some of the earliest pottery made and used by Native Americans in East Texas and Southeast Texas, especially south and west of the Sabine River. The earliest pottery in these regions-Tchefuncte pottery-may date as early as 2500 years ago, if not earlier (see Webb et al. 1969). Saunders and Hays (2004:16) report that Tchefuncte pottery from Louisiana has been dated as early as $2800-3400$ years B.P.

Story (1990:275) had suggested some years ago that the earliest sandy paste ceramics in the ConroeLivingston area dated from ca. 100 B.C. to A.D. 900; she termed this the Early Ceramic period of the Mossy Grove culture in inland Southeast Texas. More recent dating of archaeological components with Goose Creek Plain sandy paste pottery indicates that this distinctive plain ware was made beginning about and after 2500 years ago. Table 3 lists a range of these dated sites-some Mossy Grove, but not all (e.g., Rogers et al. 2001) - and includes sites from inland Southeast Texas and the Louisiana coast to the Sabine River basin in East Texas. The most thoroughly documented (although undated) Woodland period ceramic assemblage in the region is from the Deshazo site (Fields 1995). This site is in the Bayou Loco drainage basin in the southwestern part of Nacogdoches County, Texas. Other well-described Woodland period ceramics include several sites at Lake Sam Rayburn in the Angelina and Attoyac drainage basins in the southern and southeastern part of Nacogdoches and adjoining counties (Jelks 1965).
These dated sites range as late as ca. A.D. 900 in age, as previously indicated by Story (1990). It is possible to refine the ending date for the Woodland period to ca. A.D. 700 or 1250 years B.P. by excluding sites that have early arrow points in addition to, or instead of, Gary and Kent dart points. The latter are apparently diagnostic of the Early Ceramic period (Story 1990:275) in Southeast Texas and perhaps the beginning of the Formative Caddo period. Based on the Table 3 radiocarbon and OSL-dated summary of sites with Goose Creek Plain sherds and the presumed timing in the adoption of arrow points, then, Mossy Grove sandy paste ceramic assemblage from 4lCE309 could date conservatively to anywhere from ca. 2470-1250 years ago in the region.

\section{Manufacture and use of Bone-tempered pottery}

Bone temper was employed in the manufacture of tempered Caddo vessels from 41CE309, amounting to $15 \%$ of the Caddo vessel sherds (Table 4). The remainder of the sherds from the site are from vessels tempered with grog (i.e., crushed sherds or fired clay).

One of the technological features of the postA.D. 1300 upper Neches River basin Caddo ceramic tradition is the reliance by Caddo potters on the use of grog as the principal tempering aplastic (Perttula 2008a). Such is the situation in the ceramic assemblage at 41CE309. Farther to the east in the Angelina, Attoyac, and Sabine River drainages (see Perttula 2008b:Figure 12-3), contemporaneous Caddo ceramic complexes belonging to a different ceramic tradition are dominated by bone-tempered pottery vessels. Only the plain wares (i.e., bowls used in food serving) and decorated utility wares (i.e., used in cooking and storage tasks) at 41CE309 have bone-tempered vessels in any frequency. Bone tempering was clearly not preferred in the manufacture of fine ware vessels.

\section{Conclusions}

The abundant ceramic vessel sherds from $41 \mathrm{CE} 309$ indicate that a substantial prehistoric Caddo settlement was present at the site. The ceramic assemblage from this site is dominated by utility wares and plain wares, with a low frequency of engraved and red-slipped fine ware vessel sherds. The predominance of utility wares and plain wares would be expected at a Caddo domestic residential 
Table 3. Dated sites in eastern Texas and southwestern Louisiana with Goose Creek Plain ceramic sherds.

\begin{tabular}{lll}
\hline Site & $\begin{array}{l}\text { Radiocarbon } \\
\text { age range }\end{array}$ & Reference \\
\hline $\begin{array}{l}\text { 16CU108 } \\
\text { Lake Naconiche }\end{array}$ & $\begin{array}{l}2470-2200 \text { B.P. } \\
\text { (41NA231, 41NA236, }\end{array}$ & $\begin{array}{l}\text { Aten and Bollich 2002:Table 1 } \\
\text { 41NA285) }\end{array}$ \\
41RK222 & Perttula 2008b \\
41PK248 & 2150-1550 B.P. & Rogers et al. 2001 \\
41WA47 & 2030-1060 B.P.** & Mike Wilder, 2007 personal communication \\
41WA218 & $1900-1500$ B.P. & Greaves 2002 \\
41PK8 & 1700 B.P. & Walter Kingsborough, 2006 personal communication \\
41HR273 & $1600-1220$ B.P. & McClurkan 1968 \\
41WA185 & $1400-1280$ B.P. & Ensor and Carlson 1991 \\
\hline
\end{tabular}

*Later calibrated dates between AD 670-877 from the Boyette site (41NA285) are also associated with sandy paste pottery, but possibly also associated with the adoption of tempered Caddo wares.

**OSL dates

Table 4. Use of bone temper in the Caddo ceramic wares at 41CE309.

\begin{tabular}{lcc}
\hline Ware & No. & \% with bone temper \\
\hline Plain wares & 954 & 15.0 \\
Utility wares & 1256 & 16.2 \\
Fine wares & 113 & 1.8 \\
\hline Totals & 2323 & 15.0 \\
\hline
\end{tabular}

site, one that was probably occupied by several extended families for a generation or more. The common occurrence of brushed utility ware vessel sherds at 41CE309, as well as Maydelle Incised jars, brushed-punctated vessel sherds, and Poynor Engraved fine wares suggest that the Caddo occupation here took place sometime between ca. A.D. $1400-1560$. The primary use by Caddo potters of grog temper in the manufacture of the three ceramic wares (plain wares, utility wares, and fine wares) at the site-in conjunction with the ubiquity of brushed cooking and storage jars and several recognized varieties of Poynor Engraved-indicate that the ceramic vessels made, used, and broken at 41 CE309 are part of a distinctive post-A.D. 1400 upper Neches River basin Caddo ceramic tradition. That tradition is representative of one aspect of the material culture of Frankston phase Caddo groups, and the Caddo peoples that lived at 41 CE 309 were closely affiliated socially and technologically with other Caddo groups living to the north and west in the Neches River valley and its tributaries.

The identification of Weches Fingernail Impressed, var. Weches sherds and a fair number of plain sandy paste Goose Creek Plain, var. unspecified sherds are ceramic evidence that 41CE309 was also inhabited before ca. A.D. 1300. The more substantial of these earlier occupations was during the Woodland period by a Mossy Grove Culture group (see Story 1990).

\section{ACKNOWLEDGMENTS}

I would like to thank Bill Young for the opportunity to examine this collection of Caddo ceramic sherds. Mark Walters and Shawn Marceaux assisted in the documentation of the collection. 


\section{REFERENCES CITED}

Aten, L, E. and C. N. Bollich

2002 Late Holocene Settlement in the Taylor Bayou Drainage Basin: Test Excavations at the Gaulding Site (41JF27), Jefferson County, Texas. Studies in Archeology 40, Texas Archeological Research Laboratory, The University of Texas at Austin, and Special Publication No. 4, Texas Archeological Society, San Antonio.

Ensor, H. B. and D. L. Carlson (editors)

1991 Alabonson Road: Early Ceramic: Period Adaptation to the Inland Coastal Prairie Zone, Harris County. Southeast Texas. Reports of Investigations No. 8. Archeological Research Laboratory, Texas A\&M University, College Station.

Fields, R. C,

1995 Analysis of Native-Made Ceramics. In The Deshazo Site, Nacogdoches County, Texas, Volume 2: Artifacts of Native Manufacture, edited by D. A. Story, pp. 173-232. Studies in Archeology 21. Texas Archeological Research Laboratory, The University of Texas at Austin.

Gadus, E. F. and R. C. Fields

1997 Test Excavations at 41 WA185, Walker County, Texas. Technical Reports, No. 25. Prewitt and Associates, Inc., Austin.

Greaves, R. D.

2002 Archaeological Survey of Huntsville State Park and Excavations in 4lWA47, Walker County, Texas. Archaeological Survey Report, No. 327. Center for Archaeological Research, The University of Texas at San Antonio.

Jelks, E. B.

1965 The Arcbeology of McGee Bend Reservoir. Ph.D. dissertation, Department of Anthropology, The University of Texas at Austin.

McClurkan, B. B.

1968 Livingston Reservoir, 1965-66: Late Archaic and Neo-American Occupations. Papers No. 12. Texas Archeological Salvage Project, The University of Texas at Austin.

Perttula, T. K.

2008a The Ceramic Artifacts from the Lang Pasture Site (41AN38) and the Place of the Site within an Upper Neches River Basin Caddo Ceramic Tradition. MS on file, Archeological \& Environmental Consultants, LLC, Austin, and Coastal Environments, Inc., Baton Rouge. 2008b (Editor) Lake Naconiche Archeologv, Nacogdoches County, Texas. Results of the Data Recovery Excavations at Five Prehistoric Archeological Sites. Report of Investigations No. 60. Archeological \& Environmental Consultants, LLC, Austin.

Rogers, R., M. A. Nash, and T. K. Perttula

2001 Excavations at the Herman Bellew Site (41RK222), Rusk County, Texas. Document No. (000021. PBS\&J, Inc., Austin.

Saunders, R. and C. T. Hays

2004 Introduction: Themes in Early Pottery Research. In Early Pottery: Technology, Function, Style, and Interaction in the Lower Southeast, edited by $\mathrm{R}$. Saunders and C. T. Hays, pp. 1-22. University of Alabama Press, Tuscaloosa.

Stokes, J. and J. Woodring

1981 Native-Made Artifacts of Clay. In Archeological Investigations at the George C. Davis Site, Cherokee County, Texas: Summers of 1979 and 1980, edited by D. A. Story, pp. 135-238. Occasional Papers No. 1. Texas Archeological Research Laboratory, The University of Texas at Austin.

Story, D. A.

1990 Cultural History of the Native Americans. In The Archeology and Bioarcheology of the Gulf Coastal Plain, by D. A. Story, J. A. Guy, B. A. Burnett, M I). Freeman, J. C. Rose, D. G. Steele, B. W. Olive, and K. J. Reinhard, pp. 163-366. 2 Vols. Research Series No. 38. Arkansas Archeological Survey Research Series. Fayetteville.

Suhm, D. A. and E. B. Jelks (editors)

1962 Handbook of Texas Archeology: Type Descriptions. Special Publication No. 1. Texas Archeological Society, and Bulletin No. 4, Texas Memorial Museum. Austin.

Webb, C. H., F. E. Murphey, W. G. Ellis, and H. R. Green

1969 The Resch Site, 41HS16, Harrison County, Texas. Bulletin of the Texas Archeological Society 40:3106. 